\title{
Morpho-plasticity in Rhododendron lepidotum Wall. ex G. Don (Ericaceae) along altitudinal gradients and comments on the names used under the species complex
}

\author{
Vinay Kumar Singh and Debabrata Maity ${ }^{1}$ \\ Taxonomy and Biosystematics Laboratory, Department of Botany, University of Calcutta, \\ Ballygunge Circular Road, Kolkata - 700 019, West Bengal, India. \\ ${ }^{1}$ Corresponding author, e-mail: debmaity@yahoo.com \\ [Received 15.01.2018; Revised 24.03.2018; Accepted 27.03.2018; Published 30.06.2018]
}

\begin{abstract}
Rhododendron lepidotum Wall. ex G. Don (Ericaceae) is one of the dominant species of the genus in the Himalayas, having a wide distributional range from Pakistan, India, Nepal, China and Bhutan to Myanmar. Throughout its distributional range the species experiences widely variable eco-climatic conditions and thus different morpho-forms are prevalent. A quick search reveals that about 12 names are available under this species complex, reflecting its variability in morphological characters. Presently, a study has been conducted to reassess its morphological variability among the different populations both in the field and through the examination of specimens at different Indian and foreign herbaria. Several important parameters, both vegetative and reproductive were identified and examined to test the faithfulness of these characters of diagnostic value. PCA and UPGMA analysis were also performed to confirm the findings. Relevant literatures were critically examined to understand the reliability of different names published under the species complex. Present study recognized three well defined 'morphoforms and has been compared for better understanding. Apparent reliability in diagnostic features of the presently recognized Form I is corroborative with $R$. salignum Hook.f.

The status of the taxa Rhododendron lepidotum Wall. ex G. Don, $R$. salignum Hook. $f$., $R$. obovatum Hook. $f$., $R$. elaeagnoides Hook. $f$., R. lepidotum var. elaeagnoides (Hook. $f$.) Franch., $R$. sinolepidotum Balf..f., $R$. cremnastes Balf.f. \& Farrer, R. lepidotum var. album H.H. Davidian, $R$. lepidotum var. minutiforme H.H. Davidian, R. lepidotum subsp. salignum (Hook. $f$.) Pradhan \& Lachungpa and $R$. lepidotum subsp. obovatum (Hook. f.) Pradhan \& Lachungpa are discussed and their morpho-plasticity are addressed. Only two names $R$. lepidotum Wall. ex G. Don subsp. lepidotum and R. lepidotum Wall. ex G. Don subsp. salignum (Hook. f.) are accepted. All other names are considered as synonyms under these two taxa as also advocated by some other previous authors.
\end{abstract}

Key words: Rhododendron lepidotum, Himalayas, morpho-plasticity, synonyms, morphometry

\section{INTRODUCTION}

Rhododendron lepidotum Wall. ex G. Don is one of the densely lepidote species of the largest genus Rhododendron L. in Ericaceae, distributed extensively in the Himalayas, from Pakistan (http://www.tropicos.org/Name/50065009? projectid=32), India, Nepal, China, Bhutan to Myanmar (Hanbi \& Chamberlain 2005). In India, the species is distributed in both the Himalayas from Jammu \& Kashmir, Himachal Pradesh, Uttarakhand, Sikkim, West Bengal (Darjeeling) to Arunachal Pradesh and in the North-Eastern states of the country like Assam, Manipur and Nagaland (Bhattacharya \& Sanjappa 2014). The species experiences variety of climatic, edaphic and geographical conditions, i.e. slope, aspect, light, temperature, 
humidity and precipitation, etc. as its distribution ranges from nearly $2100 \mathrm{~m}$ to about $4500 \mathrm{~m}$ asl. Consequently, it shows much plasticity in several morphological features, both vegetative as well as reproductive as a response to these different environmental conditions. Time to time several taxa, both species and infra-species, had been recognized and described by different workers, mostly based on the superficial characters. At present nearly 12 names are available in this species complex (www.catalogueoflife.org; www.theplantlist.org; www.efloras.org; www.eol.org; plants.jstor.org;www.ipni.org;www.indiabiodiversity.org) (Table 1).

Table 1. Names available under R. lepidotum complex with year of establishment and their conventional status.

\begin{tabular}{|c|l|c|c|}
\hline $\begin{array}{c}\text { S. } \\
\text { N. }\end{array}$ & \multicolumn{1}{|c|}{ Names of taxa } & $\begin{array}{c}\text { Years of } \\
\text { establishment }\end{array}$ & $\begin{array}{c}\text { Conventional } \\
\text { status }\end{array}$ \\
\hline 1. & R. lepidotum Wall. & 1829 & nom. nud., nom. inval. \\
\hline 2. & R. lepidotum Wall. ex G. Don & 1834 & Accepted \\
\hline 3. & R. salignum Hook.f. & 1849 & Synonym \\
\hline 4. & R. obovatum Hook $f$. & 1849 & Synonym \\
\hline 5. & R. elaeagnoides Hook. $f$. & 1849 & Synonym \\
\hline 6. & $\begin{array}{l}\text { R. lepidotum var. elaeagnoides (Hook. f.) } \\
\text { Franch. }\end{array}$ & 1886 & Synonym \\
\hline 7. & R. sinolepidotum Balf. $f$. & 1917 & Synonym \\
\hline 8. & R. cremnastes Balf.f. \& Farrer & 1922 & Unresolved \\
\hline 9. & R. lepidotum var. album H. H. Davidian & 1982 & Synonym \\
\hline 10. & R. lepidotum var. minutiforme H. H. Davidian & 1982 & Synonym \\
\hline 11. & $\begin{array}{l}\text { R. lepidotum subsp. salignum (Hook. f.) } \\
\text { Pradhan \& Lachungpa }\end{array}$ & 1990 & Synonym \\
\hline 12. & $\begin{array}{l}\text { R. lepidotum subsp. obovatum (Hook. f.) } \\
\text { Pradhan \& Lachungpa }\end{array}$ & 1990 & Synonym \\
\hline
\end{tabular}

Don (1834) had validated the name Rhododendron lepidotum Wall. ex G. Don based on the collections of Wallich (1829) from Nepal, recognizing the characters, viz. widely branched shrub with lepidote scales; leaves spatulate and lanceolate, about $2.5 \mathrm{~cm}$ long, attenuated at base; flowers deep pink, solitary or 2-5 together, terminal, on short pedicels; calyx lobes rounded; corolla short campanulate with roundish entire lobes; filaments wooly at base.

Hooker (1849) had recognized three more new species, viz. $R$. salignum Hook. $f$., $R$. obovatum Hook. $f$. and $R$. elaeagnoides Hook. $f$. along with the description of previously known species $R$. lepidotum Wall., collected from Sikkim Himalaya. To circumscribe all these species, Hooker (1849) considered plant habit, height, leaf characters, flower characters and pedicel length. Later, Franchet (1886) treated $R$. elaeagnoides Hook. $f$. as variety of $R$. lepidotum Wall. as R. lepidotum var. elaeagnoides (Hook. f.) Franch. Balfour (1917) had added a new species, $R$. sinolepidotum Balf. $f$. and had treated $R$. lepidotum var. elaeagnoides (Hook. $f$.) Franch. as synonym of this new species. He had characterized his species with the features of habit, leaf, scale, flower and pedicel. Balfour and Farrer (1922) had recognized another species $R$. cremnastes Balf. $f$. \& Farrer from upper Myanmar and had characterized it on the basis of same features used earlier. Davidian (1982) had treated 
and described two new varieties, $R$. lepidotum Wall. ex G. Don var. album Davidianand $R$. lepidotum Wall. ex G. Don var. minutiforme Davidian on the basis of flower color, plant habit and leaf characters. Recently, Pradhan and Lachungpa (1990) had treated $R$. salignum Hook. $f$. and $R$. obovatum Hook. $f$. as subspecies of $R$. lepidotum Wall. ex G. Don as $R$. lepidotum subsp. salignum (Hook. $f$.) Pradhan \& Lachungpa and $R$. lepidotum subsp. obovatum (Hook. f.) Pradhan \& Lachungpa.

However most of the authors including the latest contributions it is considered $R$. lepidotum Wall. ex G. Don as an accepted name and treated all other published names as synonyms under it (Royle 1835; Candolle 1838; Hooker 1852; Clarke 1882; Hutchinson 1931; Biswas 1966; Cullen 1980; Hara1982; Ghosh \& Samaddar1989; Long 1991; Hanbi \& Chamberlain 2005; Bhattacharyya 2007; Panda et al. 2008; Bhattacharyya \& Sanjappa 2014).

In the present study the morpho-plasticity in this species complex has been reexamined comprehensively and comments have been made on the status of different names published to date. In primacy, some reliability is noticed on the taxonomic status of Hooker's $R$. salignum. The nomenclature status has been reevaluated of these names through detailed morphological study of both vegetative and reproductive characters. The reliability of the result is also confirmed through morphometric analysis (UPGMA and PCA).

\section{MATERIALS AND METHODS}

Plant specimens were collected from the field, both at flowering and fruiting stages through rigorous survey. Specimens were dried, fumigated and herbarium specimens were prepared following standard method (Lakshminarasimhan 2012; Ranjan 2018). The voucher specimens are deposited at CUH. All previously collected specimens deposited at CAL, BSHC and CUH were also examined. The herbarium specimens deposited at E, K, P, BM and PE were also studied through digital images. All relevant literatures including protologues were critically examined. The type specimens were also scrutinized through high resolution digital images. Relevant field data available in herbarium were considered. The major climatic conditions at different habitat were noted.

Morphometric analysis had been carried out through PCA (Principal Component Analysis) and UPGMA (Unweighted Pair-Group Method with Arithmetical averages) following standard method (Sneath \& Sokal 1973). For this study 42 novel morphological characters both vegetative and reproductive, were considered from 20 populations (Table 3). Based on data matrix, an analysis on the taxa has done using software STATISTICA 10.0 .

\section{OBSERVATION}

After exhaustive study of the specimens collected from different places both from India and abroad three forms have been recognized. These three forms though share few to several similar characteristic features, however, there are many unique characters, both vegetative as well as reproductive, for each forms, particularly the Form I exhibits several novel characters. All these three forms are compared for important morphological parameters (Table 2). Moreover, the spatial distribution patterns are also discussed. The details of the comparative illustrations of these three forms are also given in Figure 1.

\section{Distribution and climate:}

The species is distributed extensively in the Himalayas covering Pakistan, India, Nepal, China, Bhutan and Myanmar. In India, North Indian states, i.e. Jammu \& Kashmir, Himachal 
Vinay Kumar Singh \& Debabrata Maity 69
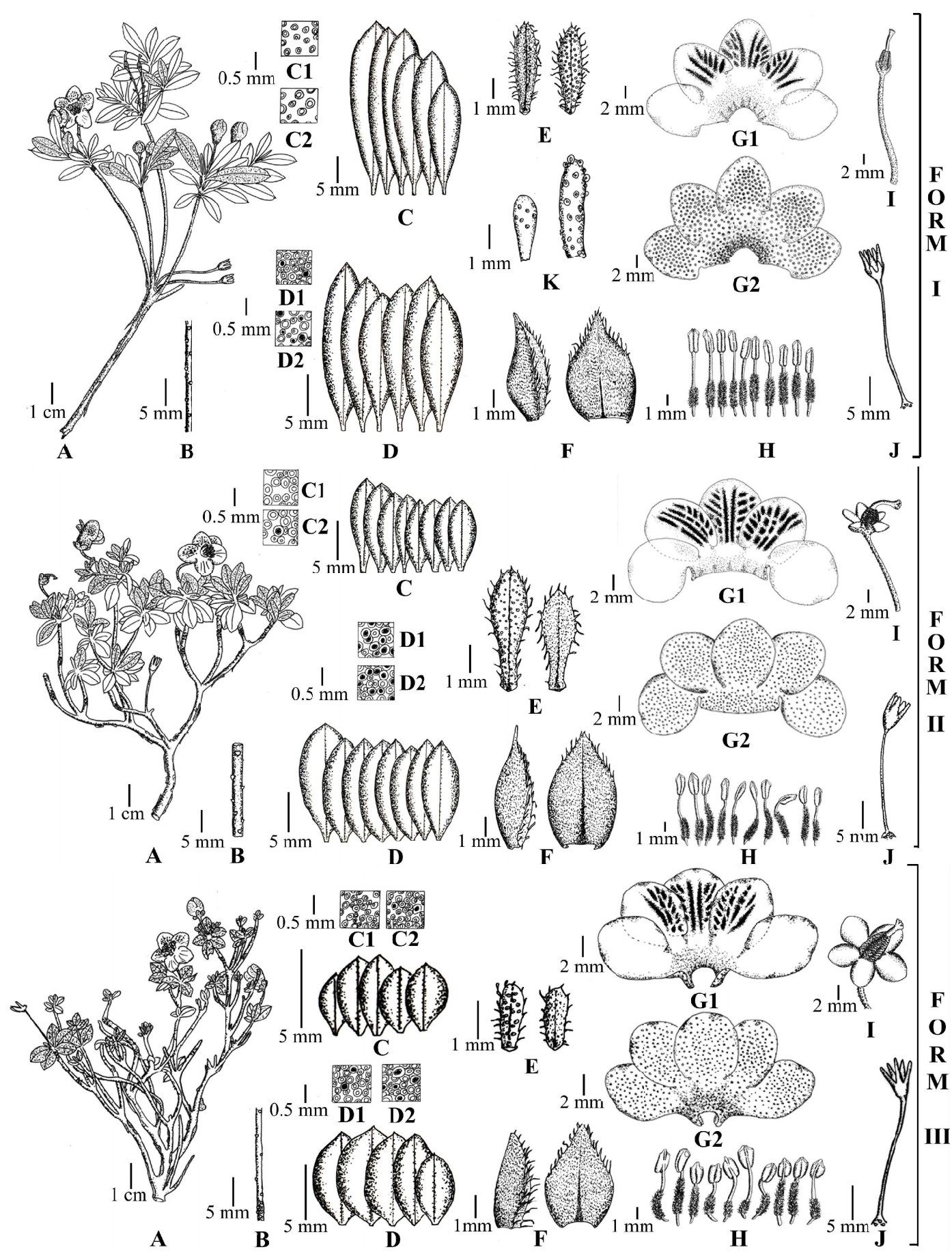

Figure 1: Rhododendron lepidotum (Form I, II \& II): A. Habit; B. Stem; C. Vegetative growth phase leaves; C1 - C2. Lepidote scales (C1- upper surface, C2 - lower surface); D. Reproductive growth phase leaves, D1 - D2. Lepidote scales (D1 - upper surface, D2 lower surface); E. scaly leaves of vegetative growth phase); F. Bract; G1 - G2. Split corolla (G1. Ventral, G2. Dorsal); H. Stamens; I. Gynoecium; J. Fruit; K. Bracteole (Only Form- I). 
70 Morpho-plasticity of Rhododendron lepidotum complex

Table 2. Comparision of major morphological characters of Forms I, II \& III.

\begin{tabular}{|c|c|c|c|c|}
\hline $\begin{array}{l}\text { S. } \\
\text { N. }\end{array}$ & Characters & Form I & Form II & Form III \\
\hline 1. & Branching & Diffuse & $\begin{array}{l}\text { Mostly profuse, } \\
\text { rarely diffuse }\end{array}$ & Profuse \\
\hline 2. & $\begin{array}{l}\text { Successive branch } \\
\text { internode length }\end{array}$ & $5-6 \mathrm{~cm}$ & $3-4 \mathrm{~cm}$ & $\begin{array}{c}\text { Less than } 3 \\
\mathrm{~cm}\end{array}$ \\
\hline 3. & $\begin{array}{l}\text { Vegetative growth } \\
\text { phase lamina shape }\end{array}$ & $\begin{array}{c}\text { Oblanceolate to } \\
\text { narrowly } \\
\text { oblanceolate }\end{array}$ & $\begin{array}{c}\text { Obovate, narrow } \\
\text { obovate or } \\
\text { elliptic }\end{array}$ & Obovate \\
\hline 4. & $\begin{array}{l}\text { Vegetative growth } \\
\text { phase lamina size }\end{array}$ & $\begin{array}{c}1.8-3.8 \times 0.6-1.2 \\
\mathrm{~cm}\end{array}$ & $\begin{array}{c}0.8-1.3 \times 0.3-0.5 \\
\mathrm{~cm} \\
\end{array}$ & $\begin{array}{c}0.3-0.4 \times 0.2- \\
0.3 \mathrm{~cm} \\
\end{array}$ \\
\hline 5. & $\begin{array}{l}\text { Vegetative growth } \\
\text { phase lamina length: } \\
\text { breadth }\end{array}$ & $4: 1$ or $3: 1$ & $2: 1$ & $1: 1$ \\
\hline 6. & $\begin{array}{l}\text { Vegetative growth } \\
\text { phase lamina base }\end{array}$ & $\begin{array}{l}\text { Attenuate or } \\
\text { cuneate }\end{array}$ & $\begin{array}{c}\text { Obtuse } \\
\text { sometimes } \\
\text { cuneate } \\
\end{array}$ & $\begin{array}{c}\text { Obtuse } \\
\text { sometimes } \\
\text { cuneate } \\
\end{array}$ \\
\hline 7. & $\begin{array}{l}\text { Reproductive growth } \\
\text { phase lamina shape }\end{array}$ & $\begin{array}{c}\text { Oblanceolate, } \\
\text { narrow- } \\
\text { oblanceolate }\end{array}$ & $\begin{array}{l}\text { Ovate, elliptic or } \\
\text { broadly elliptic }\end{array}$ & $\begin{array}{l}\text { Elliptic or } \\
\text { obovate }\end{array}$ \\
\hline 8. & $\begin{array}{l}\text { Reproductive growth } \\
\text { phase lamina size }\end{array}$ & $\begin{array}{c}1.5-1.7 \times 0.4-0.5 \\
\mathrm{~cm}\end{array}$ & $\begin{array}{c}1-1.2 \times 0.5-0.6 \\
\mathrm{~cm}\end{array}$ & $\begin{array}{c}0.4-0.8 \times 0.4- \\
0.5 \mathrm{~cm}\end{array}$ \\
\hline 9. & $\begin{array}{l}\text { Reproductive growth } \\
\text { phase lamina length: } \\
\text { breadth }\end{array}$ & $3: 1$ & $2: 1$ & $1: 1$ \\
\hline 10. & Petiole & ca. $2 \mathrm{~mm}$ & Sub-sessile & Absent \\
\hline 11. & Flower colour & $\begin{array}{c}\text { Yellow or } \\
\text { yellowish white }\end{array}$ & $\begin{array}{l}\text { Yellow, scarlet, } \\
\text { purple, dark } \\
\text { purple, yellowish } \\
\text { white to pink }\end{array}$ & $\begin{array}{c}\text { Yellow, } \\
\text { scarlet, purple, } \\
\text { dark purple, } \\
\text { yellowish } \\
\text { white to pink }\end{array}$ \\
\hline 12. & Fruit stalk & $2.1-3.1(-5) \mathrm{cm}$ & $1.6-1.8(-2.2)$ & $1.0-1.8(2.2)$ \\
\hline
\end{tabular}

Pradesh, Uttarakhand, Sikkim, West Bengal (Darjeeling), Arunachal Pradesh and NorthEastern states as Assam, Manipur, Nagaland are the home of this species. Not only this species covers a vast area as its habitat but also it covers a wide altitudinal range, consequently different climatic conditions, starting from tropical $(2100 \mathrm{~m})$ to high alpine pasture $(4500 \mathrm{~m})$ through temperate $(3000-3500 \mathrm{~m})$. After rigorous study of the herbarium specimens (BSHC, CAL, PE, CUH, K. BM, E, P, etc.) as well as recent collections it has been found that all these three forms are spatially separated from each other. Form I, Form II and Form III are restricted to subtropical to subtemperate, temperate to subalpine and subalpine to alpine pasture respectively. The annual mean rainfall (AMR), annual mean temperature (AMT) and moisture index (MI) are also quite distinct in these zones. The decrease in all these three important climatic factors (AMR, AMT and MI) with the increasing elevation has been reported by Barman et al. (2011) in Sikkim (Figure 2). 


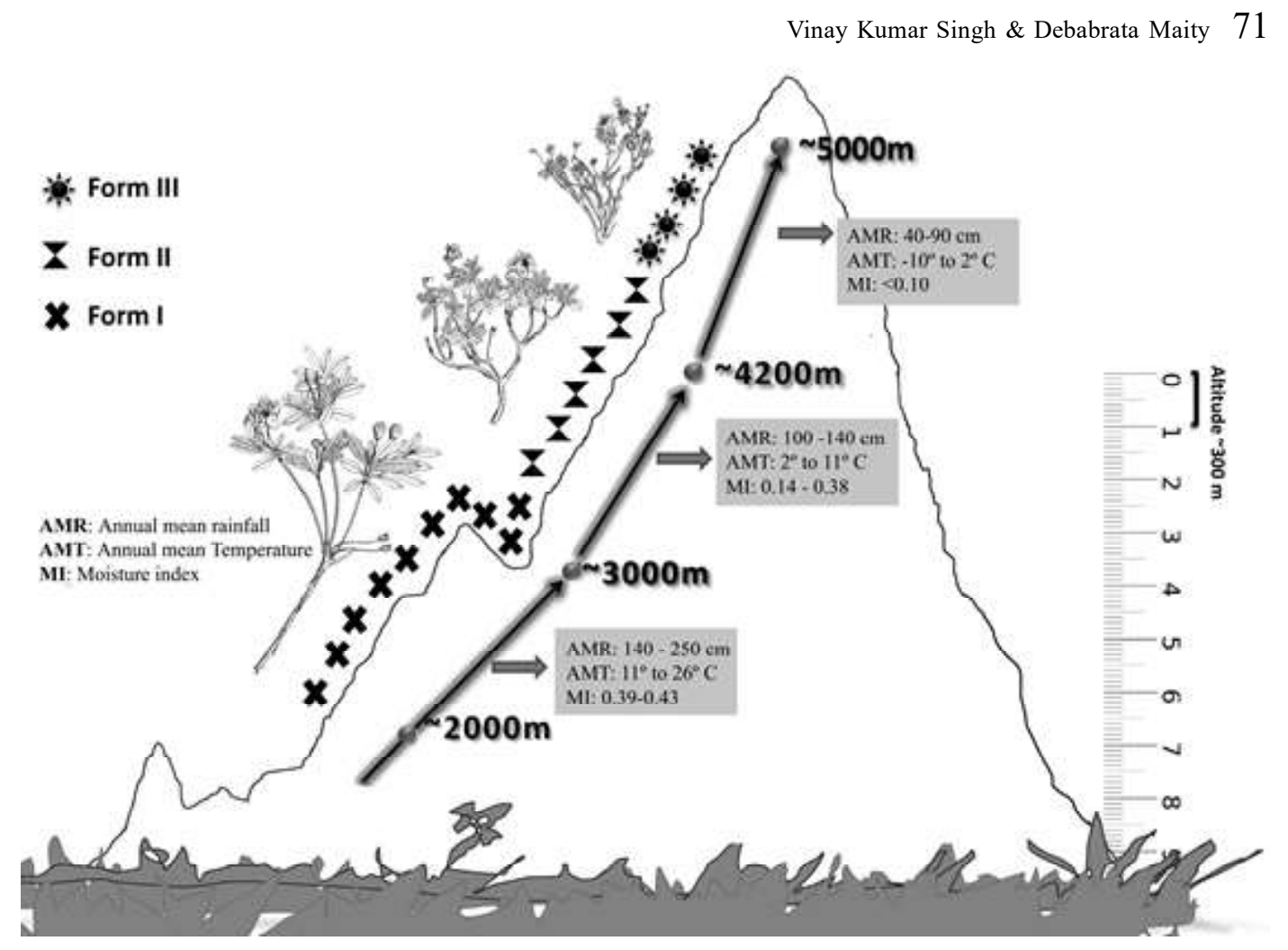

Figure 2: Spatial distribution of recognized three forms along altitude gradient with some major climatic parameters.

Comparative statement of vegetative and reproductive characters of three forms:

Habit: Plants in general are diffusely or profusely branched. Form I, a low altitude inhabitant exhibits larger growth form as to $2.5 \mathrm{~m}$ tall with lax, diffusely branched habit, whereas in other two Forms the plants are comparatively much smaller, even to only $0.4 \mathrm{~m}$ tall, densely branched, congested, bushy, often having a dome-shaped appearance. In a rare case under shade it is recorded that the plants are of nearly $1 \mathrm{~m}$ high in Form II.

Stem: The nature of stem in the studied Forms has notable distinguishing potentiality. In Form I successive branch internodal length is $5-6 \mathrm{~cm}$ and these are slender, elongated, dark gray with few lenticels. However, in Form II and Form III, stems are comparatively light gray with many lenticels and ranging the length of $3-4 \mathrm{~cm}$ and $\hat{A} 3 \mathrm{~cm}$ respectively. The stem is thick in form II. Bark exfoliates as long strips in Form I, whereas in Form II and III twisting flakes type of bark exfoliation is noticed.

Leaves: Lamina shapes are apparently dimorphic in $R$. lepidotumas vegetative growth phase leaves (VGPLs) and reproductive growth phase leaves (RGPLs). In Form I, both types of leaves are narrowly oblanceolate lamina with a length to breadth ratio of $4: 1$ or 3 $: 1$, whereas Form II and Form III has obovate, narrow obovate, broadly elliptic or elliptic lamina, with a length to breadth ratio of $2: 1$ and $1: 1$ respectively.

In all Forms, VGPLs are dark olive green adaxially and pale olive green abaxially on drying. RGPLs are grayish-brown adaxially and olive-yellow abaxially in Form I whereas in Form II and Form III these are yellowish brown adaxially and rusty yellow abaxially on drying. Notably, in Form I VGPLs are larger and RGPLs are smaller whereas in Form II and 

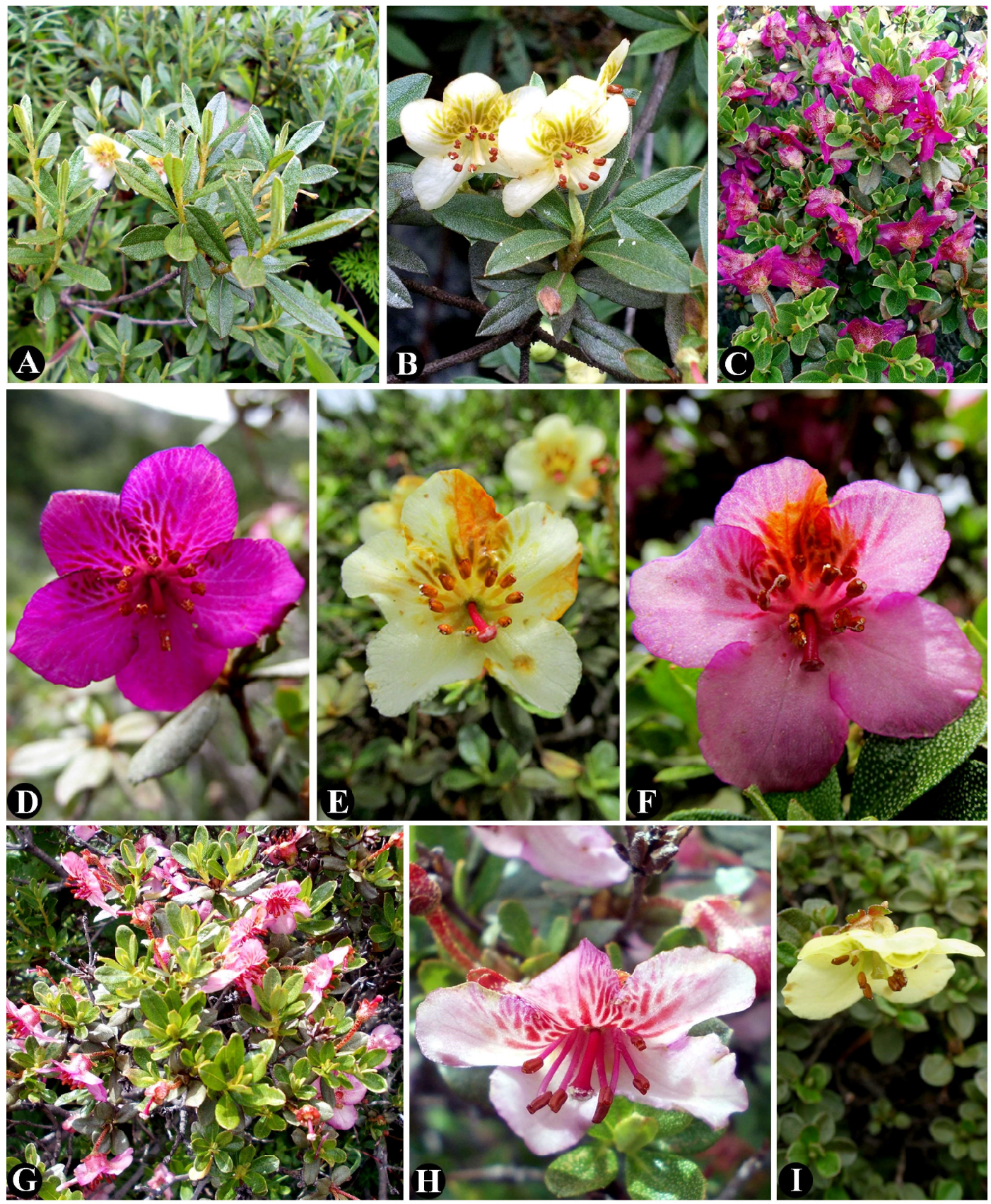

Figure 3: Rhododendron lepidotum: A - B. Form I (A. Habit; B. Flower); C - F. Form II (C. Habit; D, E \& F. Flower); G - I. Form III (G. Habit; H \& I. Flower)

III lamina length exhibiting reverse condition as VGPLs are smaller and RGPLs are larger. Petioles are ca. $2 \mathrm{~mm}$ long in Form I whereas leaves are subsessile and absent in Form II and Form III respectively.

Vegetative growth phase starts with scale leaves which are ciliate along margins and present in all forms. The scale leaves number are 1-2 in Form I and Form III, whereas 4-6 
in Form II. Lepidote scales on lamina are either exclusively yellowish or both yellowish and rusty in all forms.

In Form I, VGPL sare with exclusively yellowish lepidote scales on both the surfaces, having density $\pm 8 / \mathrm{mm}^{2}$ and $\pm 7 / \mathrm{mm}^{2}$ adaxially and abaxially respectively. These scales on adaxial surface are of equal diam., whereas, abaxial surface scales are of unequal diam. On RGPLs scales are $\pm 17 / \mathrm{mm}^{2}$ on adaxial surface and $\pm 14 / \mathrm{mm}^{2}$ on abaxial surface with the color ratio is $8: 1$ (Yellow : Rusty) on adaxial surface and in $3: 1$ (Yellow : Rusty) on abaxial surface.

In Form II, on VGPLs lepidote scales are $\pm 10 / \mathrm{mm}^{2}$ on adaxial surface and $\pm 8 / \mathrm{mm}^{2}$ on abaxial surface. All scales are yellow on adaxial surface, however, on abaxial surface very few rusty scales are observed in between yellow scales (Yellow 34 : Rusty 1).On RGPLs there are $\pm 16 / \mathrm{mm}^{2}$ scales on adaxial surface and $\pm 14 / \mathrm{mm}^{2}$ scales on abaxial surface. The scale color ratio is $2: 1$ (Yellow : Rusty) on adaxial surface and 1:1 (Yellow : Rusty) on abaxial surface.

In Form III, scales are $\pm 14 / \mathrm{mm}^{2}$ on adaxial surface and $\pm 12 / \mathrm{mm}^{2}$ on abaxial surface and as in Form I and Form II, here too all scales are yellow on adaxial surface, though, on abaxial surface many rusty scales observed in between yellow scales (Yellow 7 : Rusty 1).On RGPLs scales are $\pm 17 / \mathrm{mm}^{2}$ on adaxial surface and $\pm 15 / \mathrm{mm}^{2}$ are on abaxial surface. The color ratio is $7: 1$ (Yellow : Rusty) on adaxial surface and $4: 1$ (Yellow : Rusty) on abaxial surface.

Lepidote scales turns white and conspicuous in old RGPLs of Form I but these are inconspicuous in Form II and Form III.

Inflorescence: The inflorescence is with two or more flowers in Form I and Form II whereas in Form III flower is mostly solitary.

Flower: Flower color is much variable in this species complex from yellow, scarlet, purple, dark purple, yellowish-white to pink (Figure 3). In form I, however, flower color is almost exclusively yellow or yellowish white, rarely scarlet flowers observed in Nepal specimens. Pedicels are $1.8-4(-5) \mathrm{cm}$ long in Form I, whereas pedicels are short, only $1-1.5 \mathrm{~cm}$ long in other two Forms. Bracts are smaller in Form III. Notably, 1 or 2 bracteoles are also observed in Form I, however, bracteoles are absent in other two Forms.

Calyx: Lobes are heteromorphic. In Form I, lobes are usually oblong, smaller c. $1.8 \times 1.5$ $\mathrm{mm}$ and erect, whereas in other two forms lobes are obovate, larger, more than $2.2 \times 2.2 \mathrm{~mm}$ and much spreading.

Corolla: Lobes are broadly ovate and always c. $8 \times 8 \mathrm{~mm}$ in Form I, whereas in Form II and III lobes are broadly ovate to sub-orbicular, 6-8 $\times 6-9 \mathrm{~mm}$ in Form II and Form III.

Androecium: Stamens are 10 and are variable in length. Hairy zone in all filaments is restricted at the middle or lower middle part of the filament in Form I. However, in other two forms often at least one or two filaments are hairy almost throughout their length. Anthers are more or less oblong in Form I. However, in other two forms it is obovoid to broadly obovoid. Filaments are of variable length, longer $(7-9 \mathrm{~mm})$ in Form I, whereas, other two forms have shorter, $5-8 \mathrm{~mm}$ long filaments.

Gynoecium: Comparatively short and slender, often with longer style in Form I, whereas in Form II and Form III it is short and thick with short style.

Fruit: Septicidal capsules. Stalk is more elongated $2.5-4(-5) \mathrm{cm}$ long in Form I, whereas in other two Forms it is comparatively shorter, only up to $2 \mathrm{~cm}$ long. 


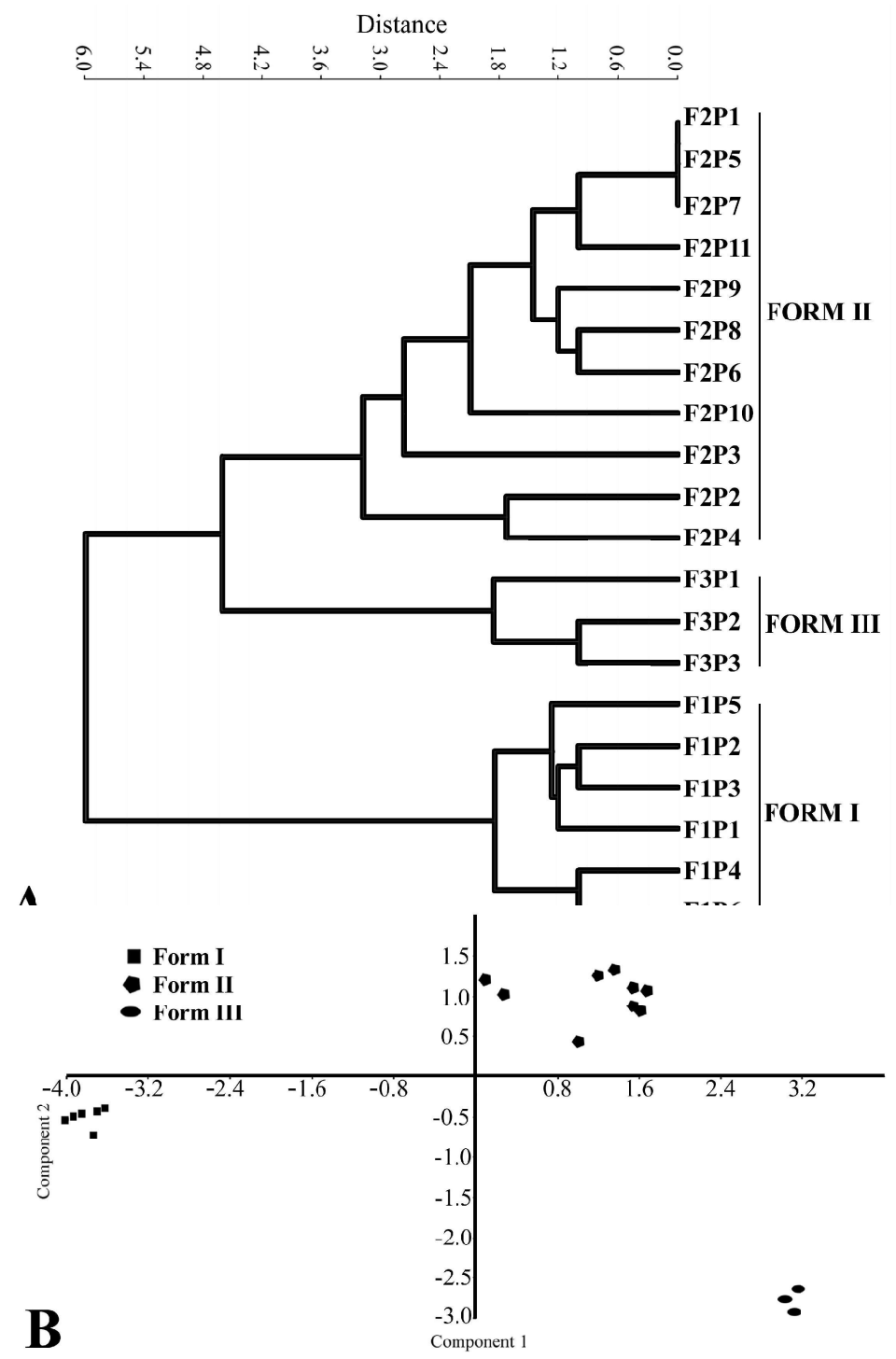

Figure 4: Morphometric analysis: A. UPGMA (Unweighted Pair-Group Method with Arithmetical averages); B. PCA (Principal Component Analysis)

\section{Morphometric Analysis}

Morphometric analysis of 20 populations using 42 character states have been performed (Table 3). Two major clusters are found in UPGMA dendrogram constructed through cluster analysis. The first cluster consists of only Form I, while the second cluster comprises both Form II and Form III. Though, the latter two forms are also quite distinct from each other (Figure 4).

The PCA ordination of the first two canonical functions identifies the distinct position of three forms. The PCA analysis provides distinct clusters for each form. Notably, this study also revealed morphological variations within populations of individual forms. 
Table 3. Morphological characters and their states used for morphometric analysis of 20 populations representing three Forms of $R$. lepidotum

\begin{tabular}{|c|c|c|}
\hline S.N. & Characters attribute & Character states \\
\hline 1. & Plant height & Less than $2 \mathrm{~m}(0)$; more than $2 \mathrm{~m}(1)$ \\
\hline 2. & Branching & Lax $(0) ;$ dense $(1)$ \\
\hline 3. & $\begin{array}{l}\text { Successive branch internodal } \\
\text { length }\end{array}$ & $\begin{array}{l}\text { More than } 5 \mathrm{~cm}(0) ; 3-4 \mathrm{~cm}(1) \text {; less than } \\
3 \mathrm{~cm}(2)\end{array}$ \\
\hline 4. & $\begin{array}{l}\text { Vegetative growth phase lamina } \\
\text { size }\end{array}$ & $\begin{array}{l}\text { Less than } 0.5 \mathrm{~cm}(0) ; 0.8-1.3 \mathrm{~cm} \mathrm{(1)} \text {; } \\
\text { more than } 1.5 \mathrm{~cm} \mathrm{(2)}\end{array}$ \\
\hline 5. & $\begin{array}{l}\text { Vegetative growth phase lamina } \\
\text { shape }\end{array}$ & $\begin{array}{l}\text { Obovate or elliptic }(0) \text {; oblanceolate or } \\
\text { narrow-oblanceolate }(1)\end{array}$ \\
\hline 6. & $\begin{array}{l}\text { Length breadth ratio of vegetative } \\
\text { growth phase lamina }\end{array}$ & $4: 1(3: 1)(0) ; 2: 1(1) ; 1: 1(2)$ \\
\hline 7. & $\begin{array}{l}\text { Vegetative growth phase lamina } \\
\text { base }\end{array}$ & Attenuate or cuneate $(0)$; obtuse (1) \\
\hline 8. & $\begin{array}{l}\text { Reproductive growth phase } \\
\text { lamina size }\end{array}$ & $\begin{array}{l}\text { Less than } 1 \mathrm{~cm}(0) ; 1-1.5 \mathrm{~cm}(1) \text {; More } \\
\text { than } 1.5 \mathrm{~cm}(2)\end{array}$ \\
\hline 9. & $\begin{array}{l}\text { Reproductive growth phase } \\
\text { lamina shape }\end{array}$ & $\begin{array}{l}\text { Obovate or elliptic }(0) \text {; oblanceolate or } \\
\text { narrow elliptic (1) }\end{array}$ \\
\hline 10. & $\begin{array}{l}\text { Length breadth ratio of } \\
\text { reproductive growth phase } \\
\text { lamina }\end{array}$ & $3: 1(4: 1)(0) ; 2: 1(1) ; 1: 1(2)$ \\
\hline 11. & $\begin{array}{l}\text { Reproductive growth phase } \\
\text { lamina base }\end{array}$ & Attenuate or cuneate $(0)$; obtuse (1) \\
\hline 12. & $\begin{array}{l}\text { Leaf color on drying reproductive } \\
\text { growth phase: Adaxial }\end{array}$ & Grayish-brown (0); rusty -brown (1) \\
\hline 13. & $\begin{array}{l}\text { Leaf color on drying reproductive } \\
\text { growth phase: Abaxial }\end{array}$ & Olive-yellow (0); rusty-yellow (1) \\
\hline 14. & $\begin{array}{l}\text { Scale distribution: vegetative } \\
\text { growth phase lamina: upper } \\
\text { surface }\left(\mathrm{mm}^{2}\right)\end{array}$ & $\pm 8(0) ; \pm 10(1) ; \pm 14(2)$ \\
\hline 15. & $\begin{array}{l}\text { Scale distribution: vegetative } \\
\text { growth phase lamina: lower } \\
\text { surface }\left(\mathrm{mm}^{2}\right)\end{array}$ & $\pm 8(0) ; \pm 12(1)$ \\
\hline 16. & $\begin{array}{l}\text { Scale color on reproductive } \\
\text { growth phase lamina : upper } \\
\text { surface [Yellow : Rusty] }\end{array}$ & $8: 1(0) ; 2: 1(1)$ \\
\hline 17. & $\begin{array}{l}\text { Scale color on reproductive } \\
\text { growth phase lamina : lower } \\
\text { surface [Yellow: Rusty] }\end{array}$ & $4: 1(0) ; 1: 1(1)$ \\
\hline 18. & $\begin{array}{l}\text { Vegetative growth phase lamina } \\
\text { area }\end{array}$ & $\begin{array}{l}\text { More than } 70 \mathrm{~mm}^{2}(0) \text {; less than } 40 \\
\mathrm{~mm}^{2}(1)\end{array}$ \\
\hline
\end{tabular}




\begin{tabular}{|c|c|c|}
\hline S.N. & Characters attribute & Character states \\
\hline 19. & $\begin{array}{l}\text { Reproductive } \text { growth } \\
\text { lamina area }\end{array}$ & $\begin{array}{l}\text { More than } 40 \mathrm{~mm}^{2}(0) \text {; less than } 30 \\
\mathrm{~mm}^{2}(1)\end{array}$ \\
\hline 20. & $\begin{array}{l}\text { White scales in old reproductive } \\
\text { growth phase lamina }\end{array}$ & Prominent (0); inconspicuous (1); \\
\hline 21. & Leaves state & \pm Drooping (0); flaccid (1) \\
\hline 22. & Leaf scar & Inconspicuous (0); conspicuous (1) \\
\hline 23. & $\begin{array}{l}\text { Vegetative growth phase leaves } \\
\text { distribution }\end{array}$ & $\begin{array}{l}\text { Restricted at branch tip (0); throughout } \\
\text { twig (1) }\end{array}$ \\
\hline 24. & Petiole & Absent (0);0-0.5 mm (1); c. $2 \mathrm{~mm} \mathrm{(2)}$ \\
\hline 25. & $\begin{array}{l}\text { Vegetative growth phase scale } \\
\text { leaves number }\end{array}$ & $2-3(0) ; 5-6(1)$ \\
\hline 26. & Flower number & Two or more $(0)$; one $(1)$ \\
\hline 27. & Flower color & $\begin{array}{l}\text { Yellow, yellowish-whitish (0); crimson to } \\
\text { purple or pinkish (1) }\end{array}$ \\
\hline 28. & Pedicel length & $1-1.5 \mathrm{~cm}(0) ;$ more than $1.5 \mathrm{~cm}(1)$ \\
\hline 29. & Calyx lobe shape & Obovate $(0)$; oblong $(1)$ \\
\hline 30. & Calyx lobe size & $1-2 \times 0.5-1.5 \mathrm{~mm}(0) ; 2-3 \times 2-2.5(1)$ \\
\hline 31. & Calyx lobe & $\begin{array}{l}\text { Appressed to ovary }(0) \text {; spreading away } \\
\text { from ovary (1) }\end{array}$ \\
\hline 32. & Corolla lobe shape & Ovate $(0)$; obovoid $(1)$ \\
\hline 33. & Corolla lobe size & Less than $7 \times 7 \mathrm{~mm}(0)$ ca. $8 \times 8 \mathrm{~mm}(1)$ \\
\hline 34. & Anther length & $1.8-2 \mathrm{~mm}(0) ; 2-2.5(1)$ \\
\hline 35. & Filament length & $5-8 \mathrm{~mm}(0) ; 7-9 \mathrm{~mm} \mathrm{(1)}$ \\
\hline 36. & Style length & $3-4 \mathrm{~mm}(0) ;$ c. $2 \mathrm{~mm}(1)$ \\
\hline 37. & Fruit stalk & Up to $2 \mathrm{~cm}(0) ;$ more than $2.5 \mathrm{~cm} \mathrm{(1)}$ \\
\hline 38. & Bract length & Less than $5 \mathrm{~mm}(0)$; more than $5 \mathrm{~mm}(1)$ \\
\hline 39. & Bracteole & Present $(0) ;$ absent $(1)$ \\
\hline 40. & Bark & Thick barked (0); thin barked (1) \\
\hline 41. & Bark color & Grayish (0); brownish (1) \\
\hline 42. & Bark exfoliation & In long strips (0); in small flakes (1) \\
\hline
\end{tabular}

\section{RESULT AND DISCUSSION}

Morphological plasticity is well known phenomenon in the plant world, basically in rapidly changing climate (Bradshaw1965; Nicotara et al. 2010). Rapid change in climate alters the availability of resources and the conditions that are crucial to plant performance (Nicotara et al. 2010). Because plants are static organisms, to survive they acclimatize through these minor changes, 'adjustments' to be precise. When the conditions remain same for generations, plants fix these change genetically, which is a slow process and leads to speciation (Scheiner et al, 2017). The Himalaya, which is vast and extensively rugged, having the highest peaks of the world, determines the availability of resources that plants need to survive. The "wish to survive' leads to modifications in all possible parts of the plants to exploit these 'limited resources'. Further, there are neighbors those who are also competing for the same, raising the extra pressure and it is true as Himalaya is biodiversity rich. Thus, acclimatization is the beginning of standing firmly against all the harsh prevailing conditions. 
Taxon described based on superficial, variable morphological traits, arise mostly due to variable microclimate often lead to confusion. These morphological traits are not permanent and thus must not be considered for circumscription of any taxon. $R$. lepidotum, a widely distributed species throughout the Himalayas, ranges from Pakistan, Nepal, China as well as North Eastern states of India and Bhutan to Myanmar experiences a wide array of climatic conditions. Not only this species covers a vast area as its habitat but also it covers a wide altitudinal range, consequently different climatic conditions starting from subtropical (2100 $3000 \mathrm{~m})$, temperate $(3000-3500 \mathrm{~m})$ to high alpine pasture $(3500$ - above $4500 \mathrm{~m})$ (Figure 2). Each of these climates has uniqueness in their environment as well as in factors that are associated with topography, geography and soil viz. slope, aspect, light availability, temperature, precipitation, soil nutrients, etc. (Figure 2)

In this context, $R$. lepidotum also exhibits a wide range of morphological variations. The present study also established the vast morphological plasticity in both vegetative and reproductive characters across the populations. Based on these variable characters several new taxa had been established by different workers. All total about 12 names were available in this group (Table 1).

Notably, all published taxa mentioned above are under R. lepidotum species complex because of overall similarity in vegetative and reproductive morphological characters, particularly the flowering and fruiting parameters as well as the lepidote nature of this plant. Importantly, after extensive study three morpho-forms have been recognized throughout its distributional ranges. These three forms are nicely separated spatially across the altitudinal gradient (Figure 2). Form I is a low altitude resident, Form II mid-altitudinal resident and Form III high altitudinal resident. After extensive study in the field as well as laboratory and through morphometric analysis it has been seen that the Form I is the most potential candidate with more unique diagnostic characters than other two. These characters are less variable to almost constant. Other two forms though separated by few morphological characters, however, overall similarity is more and thus clustered in a single clad in the morphometric analysis (Figure 4). Morphometric analysis using 42 characters states provides a reliable picture in this context.

The low altitudinal resident Form I corroborates with Hooker's R. salignum, which was described from subtropical to temperate forests of Chungthang, North Sikkim around $2100 \mathrm{~m}$ amsl. Some of the characters in this form are found to be very static and of diagnostic value (Table 2). During present study this form was also collected from lower Chhaten and Lachen (around $2200-2800 \mathrm{~m}$ amsl). Form I is also recorded in Pakistan (Hazara, Azad Kashmir), India (Himachal Pradesh: Beas Nala, Rotang; Uttarakhand: Badrinath; Sikkim: Chungthang, Lachung, Chhaten and Lachen; Arunachal Pradesh: Tawang), Nepal (Parbati Kund, Jongim, Thasa Khrkha, Wolangchung, Gola, Bagmati Zone, Dhunche), China (Yadong, Nyingchi, Jilong, Nyalamu, Daini) and Bhutan (Trashi Yangse Chu) in $1600 \mathrm{~m}$ to $3500 \mathrm{~m}$ amsl. The slender,tall growth habit, elongated branch internodes, exfoliation of barks as long stripes, narrow oblanceolate leaves, exclusively yellow or yellow white flowers, comparative erect, smaller calyx lobes, much elongated pedicels as well as fruiting stalks, etc. make this Form very distinct from the other populations throughout its distributional range in the Himalaya.

Form II and Form III, both are comparatively much high altitude inhabitants are quite overlapping in their most of the characters. Form II is distributed in India (Uttarakhand: Yamunotri, Mapang; Sikkim: Thangu, Chhangu, Kalapathar, , Dzongri, Yamde), Nepal (Cha Bing Kharka, Sano Pokhani, Sean Kharka), China (Medog, Nyalam) and Myanmar (Chimili) in $3200 \mathrm{~m}$ to $4500 \mathrm{~m}$ masl., whereas Form III is distributed in India (Sikkim: Giagion, Yongri), 
Nepal (Nango La, Tutu La, Gosain Kund) and China (Nyalam, Yadong) in above $4200 \mathrm{~m}$ amsl. Both of the Forms show mostly bushy, stunted growth habit, with profuse branching pattern, shorter branch internodes, broadly obovate leaves, range of variable flower color, smaller pedicel length and fruit stalk compare to Form I. Possibly the tall, slender growth habit of Form I is related to subtropical temperate climate, where most of the plant species shows such type of growth form, whereas stunted, bushy growth habit is the characteristics of alpine habitat plants as the Form II and Form III exhibit such growth form.

Rhododendrons are well known for hybrids and polyploids (Milne et al. 1999; Jones et al. 2007), so may be the overlapping characters are the result of these processes because the overlapping characters were found to be associated with the Form's proximity. The populations which were found to be isolated distantly were pure at least in the case of Form I. Again as vegetative reproduction is so much common in Rhododendrons, the hybrids and polyploidy can be maintain through vegetative reproduction (Herben et al. 2017), consequently maintains the variability. Several studies agree with the general statement that asexual reproduction is frequent for plants in adverse environments (Chiariello \& Gulmon 1991; Kudo 1991; Krahulec 1994; Chambers 1995). Future detailed investigation is needed in $R$. lepidotum species complex to verify the intraspecific variability.

The present study advocates for treating the entire complex under the single species R. lepidotum. However, Form I which is corroborating with Hooker's R. salignum must be treated as distinct subspecies as previously advocated by Pradhan and Lachungpa (1990). Therefore the name is restrained here for general acceptance. An enumeration of names is given below.

\section{Taxonomic treatment}

Rhododendron lepidotum Wall. ex G. Don, Gen. His. 3:845.1834; C.B. Clarke in Hooker, J.D., Fl. Brit. India 3: 471. 1882; Biswas, P1. Darjeeling \& Sikkim Him. 540.1966; Cullen, Notes Roy. Bot. Gard. Edinburgh 39: 149. 1980; Pradhan \& Lachungpa, Sikkim Himalayan Rhodod. 65. 1990; D.G. Long in Grierson \& D.G. Long, Fl. Bhutan 2: 384. 1991; Hanbi \& Chamberlain in Wu et al., Fl. China 14: 310. 2005; Sastry \& Hajra, Rhodod. India 56. 2010; Bhattacharyya \& Sanjappa in Sanjappa \& Sastry, Fas. India 25: 39. 2014.

\section{subsp. lepidotum}

[Synonyms: $R$. obovatum Hook. $f$., $R$. elaeagnoides Hook. $f$., $R$. lepidotum var. elaeagnoides (Hook. $f$.) Franch., $R$. sinolepidotum Balf. $f ., R$. cremnastes Balf. $f$. \& Farrer, $R$. lepidotum var. minuteforme H.H. Davidian, R. lepidotum subsp. obovatum (Hook. f.) Pradhan \& Lachungpa]

subsp. salignum (Hook.f.) Pradhan \& Lachungpa, Sikkim Himalaya Rhodod. 65. 1990.

Basionym: R. salignum Hook.f., Rhodod. Sikkim Himalaya 3: t. 23A. 1851.

[Synonym: R. lepidotum var. album H.H. Davidian ]

\section{Acknowledgements}

Authors are thankful to University Grants Commission (UGC) for financial support to carry out this research program. They thank Ministry of Environment, Forest and Climate Change, Govt. of India for partial financial assistance to our research program. They are also grateful to the Department of Forests, Environment \& Wildlife Management Department and Home Department, Govt. of Sikkim, Superintendent of Police, Gangtok for permitting and supporting 
our field visit. Authors also express our gratitude to Prof. G.G. Maiti for his kind help and suggestions for improving this article. They thank Dr. Sentu K. Dey for his different kinds help. Authors are grateful to Prof. A. P. Das, Editor, Pleione and reviewers for their constructive comments on our manuscript.

\section{LITERATURE CITED}

Balfour, I. B. 1917. New Species of Rhododendron, II. Notes Roy. Bot. Gard. Edinburgh 10: $155-157$.

Balfour, I.B. \& Farrer, R.J. 1922. Rhododendron: Diagnoses Specierum Novarum, II. Notes Roy. Bot. Gard. Edinburgh 13: 253 - 254.

Barman, D.; Medhi, R.P.; Parthasarathy, U.; Jayarajan, K. \& Parthasarathy, V.A. 2011. A geospatial approach to diversity of Cymbidium Swartz in Sikkim. The McAllen Intern. Orchid Soc. J. 12(10): $8-16$.

Bhattacharyya, D. 2007. Revision of the genus Rhododendron L. (Ericaceae) in India, Ph.D. Thesis (unpublished), University of Calcutta, Kolkata. Pp. $83-84$.

Bhattacharya, D. \& Sanjappa, M. 2014. Rhododendron L. In: Sanjappa, M. \& Sastry, A.R.K. (eds.), Ericaceae. Fascicles of Flora of India, Botanical Survey of India. Kolkata. 25. pp. $9-157$.

Biswas, K.P. 1966. Plants of Darjeeling and the Sikkim Himalayas, Calcutta. p. 540.

Bradshaw, A.D. 1965. Evolutionary Significance of Phenotypic Plasticity in Plants. $A d v$. Genet. 13: $115-155$.

Candolle, A.P. de 1838. Ericaceae. In: A.P. de Candolle \& A.L.P.P. de Candolle (eds.), Prodr. (DC.) 7: 724. Paris.

Chambers, J.C. 1995. Disturbance, life-history strategies, and seed fates in alpine herbfield communities. Am. J. Bot. 82(3): $421-433$.

Chiariello, N.R. \& Gulmon, S.L. 1991. Stress effects on plant reproduction. In: Mooney, H.A., Winner, W.E., \& Pell, E.J. (eds.), Response of Plants to Multiple Stresses, Academic Press, London, UK. Pp. $161-188$.

Clarke, C.B. 1882. Ericaceae. In: Hooker, J.D. (ed.), The Flora of British India, vol. 3 (Caprifoliaceae to Apocynaceae): 456 - 476. L. Reeve \& Co., London.

Cullen, J. 1980. Revision of Rhododendron. 1. Subgenus Rhododendron sections Rhododendron \& Pogonanthum. Notes Royal Bot. Gard. Edinburgh 39: 1 - 207.

Davidian, H.H. 1982. A New Rhododendron species and four new varieties. J. Amer. Rhodod. Soc. 36(1): 15 - 16.

Don, G. 1834. A General History of the Dichlamydeous Plants, 3: 845. Gilbert \& Rivington Printers, London.

Franchet, A.R. 1886. Rhododendron Du Thibet Et Du Yunnan. Bull. Soc. Bot. France, 33: 234. Paris

Ghosh, R.B. \& Samaddar, U.P. 1989. The Rhododendrons of the North-East India. J. Econ. Taxon. Bot. 13(1): $205-220$.

Hanbi, Y. \& Chamberlain, D.F. 2005. Rhododendron Subsect. Lepidota. In: Wu, Z. Y.; Raven P.H. \& Hong, D.Y. (eds.), Flora of China. 14 (Apiaceae through Ericaceae): 310 - 311. Science Press, Beijing and Missouri Botanical Garden Press, St. Louis. 
80 Morpho-plasticity of Rhododendron lepidotum complex

Hara, H. 1982. Ericaceae. In: Hara, H., Charter, A.O. \& Williams, L.H.J. (eds.), An Enumeration of the Flowering Plants of Nepal. British Museum (Natural History), London. 3: 58.

Herben, T.; Suda, J. \& Klimesova, J. 2017. Polyploid species rely on vegetative reproduction more than diploids: a re-examination of the old hypothesis. Ann. Bot., 120:341-349.

Hooker, J.D. 1849. The Rhododendrons of Sikkim-Himalaya Rhododendron. L. Reeve \& Co., London.

Hooker, W.J. 1852. Rhododendron lepidotum Wall. ex G. Don, Bot. Mag. 78. t. 4657.

Hutchinson, J. 1931. New species of Asiatic Lepidote Rhododendrons. Notes Roy. Bot. Gard. Edinburgh 16 (79): 171 - 183.

Krahulec, F. 1994. Clonal behaviour in closely related plant. Folia Geobot. Phytotaxon., Praha 29(2): 277 - 289.

Kudo, G. 1991. Effects of Snow-Free Period on the Phenology of Alpine Plants Inhabiting Snow Patches. Arct. Alp. Res. 23(4): 436.

Lakshminarasimhan, P. 2012. Herbarium Techniques. In: D. Maity (ed.), Perspectives of Plant Taxonomy: Exploration, Herbarium, Nomenclature and Classification. Partha Sankar Basu, Kolkata. Pp. 7 - 24.

Long, D.G. 1991. Ericaceae. In: Grierson, A.J.C. \& Long, D.G. (eds.), Flora of Bhutan 2(1): $384-385$.

Milne, R.I.; Abbott, R.J.; Wolfe, K. \& Chamberlain, D.F. 1999. Hybridization among sympatric species of Rhododendron (Ericaceae) in Turkey: Morphological and Molecular evidence. Am. J. Bot. 86(12): $1776-1785$.

Nicotara, A.B.; Atkin, O.K.; Bonser, S.P.; Davidson, A.M.; Finnegan, E.J.; Mathesius, U.;

Poot, P.; Purugganan, M.D.; Richards, C.L.; Valladares, F. \& Kleunen, M. van , 2010. Plant phenotypic plasticity in a changing climate. Trends Pl. Sci. 15(12): $684-692$.

Panda, S.: Adhikari, A. \& Sarkar, R. 2008. Amplified description of Rhododendron lepidotum Wallich ex G. Don (Ericaceae) with a note on its leaf-stomata. Pleione 2(2): 197 202.

Pradhan, U.C. \& Lachungpa, S.T. 1990. Sikkim-Himalayan Rhododendrons. p. 65. Primulaceae Books, Kalimpong.

Ranjan, V. 2018. Herbaria: A systematic repository of plant specimens for research. In: D. Maity (ed.), Taxonomy: Theory and Practice (Proceedings....\& CC). Government of India, Department of Botany, University of Calcutta, Kolkata. Pp. 96 - 118.

Royle, J.F. 1835. Illustrations of the Botany and other Branches of the Natural History of the Himalayan Mountains, and of the Flora of Cashmere. W.H. Alland \& Co. London. 1, t. $64: 260$.

Scheiner, S.M.; Barfield, M. \& Holt, R.D., 2017. The genetics of phenotypic plasticity. XV. Genetic assimilation, the Baldwin effect, and evolutionary rescue. Ecol. Evol. 7(21): $8788-8803$.

Sneath, P.H.A. \& Sokal, R.R. 1973. Numerical Taxonomy. The Principles and Practice of Numerical Classification. San Francisco: Freeman. Pp. 573.

Wallich, N. 1829. Numerical list of dried specimens of plants in the Museum of the Honl. East India Company. Cat. no. 758. 